\title{
IMPLEMENTASI NILAI-NILAI PANCASILA DALAM PEMBANGUNAN SISTEM HUKUM PIDANA DI INDONESIA
}

\author{
Erfandi \\ Fraksi Persatuan Pembangunan DPR RI \\ Jl. Jenderal Gatot Subroto Jakarta 10270. Gedung Nusantara III \\ email: erfandi20@gmail.com
}

\begin{abstract}
It should be recognized the draft Penal Code or the Criminal Code applied in Indonesia was a legacy of Netherland colonialism and imperialism regime which had colonized this country for 350 years. Badly, the book which is used as criminal law guidelines is still applicable in Indonesia, although the life and traditions of society are far different from those in the Netherlands. Even though, there are a few additions and subtractions to the Criminal Code provisions, but the nature of imperialism and capitalism remains rooted in the Penal Code. Therefore, in order to revise the Penal Code voiced intensively by various elements of society lately, it is highly recommended inserting appropriate norms to the values of Pancasila as the implementation of national ideology which is complex and civilized into the criminal law system in Indonesia.
\end{abstract}

Keyword: criminal code, criminal.

\begin{abstract}
Abstrak: Harus diakui bahwa Kitab Undang-Undang Hukum Pidana, atau KUHP, yang sekarang berlaku di Indonesia merupakan peninggalan rezim kolonialisme dan imperialisme Belanda yang telah menjajah negeri ini selama 350 Tahun. Parahnya, kitab yang menjadi payung hukum pidana tersebut hingga saat ini masih tetap berlaku di Indonesia, meskipun tatanan kehidupan dan tradisi masyrakatnya sangat jauh berbeda dengan di Belanda. Sekalipun terdapat beberapa penambahan dan pengurangan terhadap ketentuan KUHP, namun watak imperialisme dan kapitalisme tetap mengakar dalam KUHP tersebut. Karenanya, dalam rangka revisi KUHP yang semakin gencar disuarakan oleh berbagai kalangan akhir-akhir ini, perlu kiranya dimasukkan norma-norma yang sesuai dengan nilai-nilai Pancasila sebagai implementasi ideologi bangsa yang majemuk dan berkeadaban, ke dalam sistem hukum pidana di Indonesia.
\end{abstract}

Kata Kunci: KUHP, pidana.

Indonesia sebagai sebuah entitas yang mengadopsi konsep negara hukum, melembagakan peran besar negara di dalam rumusan staatsidee yang sudah tercantum di dalam Pembukaan Undang-Undang Dasar Negara Republik Indonesia Tahun 1945. Dimana di dalam Pembukaan tersebut, Pemerintah Republik Indonesia dibentuk untuk memajukan kesejahteraan umum (Pembukaan UUD NRI Tahun 1945 Alinea keempat).

Pembebanan tanggung jawab untuk memajukan kesejahteraan umum tersebut, secara otomatis di bidang politik hukum, akan berimplikasi terhadap hasil produk hukum. Pembangunan dalam bidang hukum, khususnya pembangunan atau pembaruan hukum pidana, tidak hanya membangun lembaga-lembaga hukum, tetapi juga harus mencakup pembangunan substansi produkproduk hukum dan kultur yang merupakan hasil dari suatu sistem hukum dalam bentuk peraturanperaturan hukum pidana dan yang bersifat kultural yakni sikap dan nilai-nilai yang mempengaruhi berlakunya sistem hukum (Rahardjo, 1980: 84 86).

Usaha pembaharuan hukum di Indonesia yang sudah dimulai sejak proklamasi kemerdekaan tanggal 17 Agustus 1945, melalui UUD NRI Tahun 1945, tidak dapat dilepaskan dari landasan dan sekaligus tujuan nasional yang ingin dicapai seperti dirumuskan dalam Pembukaan UUD NRI Tahun 1945, khususnya alinea ke empat yaitu: "Kemudian daripada itu untuk membentuk suatu Pemerintah 
Negara Indonesia yang melindungi segenap bangsa Indonesia dan seluruh tumpah darah Indonesia dan untuk memajukan kesejahteraan umum, mencerdaskan kehidupan bangsa, dan ikut melaksanakan ketertiban dunia yang berdasarkan kemerdekaan, perdamaian abadi dan keadilan sosial, maka disusunlah Kemerdekaan Kebangsaan Indonesia itu dalam suatu UndangUndang Dasar Negara Indonesia, yang terbentuk dalam suatu susunan Negara Republik Indonesia yang berkedaulatan rakyat dengan berdasar kepada Ketuhanan Yang Maha Esa, Kemanusiaan yang adil dan beradab, Persatuan Indonesia dan Kerakyatan yang dipimpin oleh hikmat kebijaksanaan dalam Permusyawaratan/ Perwakilan, serta dengan mewujudkan suatu Keadilan sosial bagi seluruh rakyat Indonesia. Dari perumusan di atas dapat diketahui adanya tujuan "perlindungan masyarakat" (social defence) dan "kesejahteraan masyarakat" (social welfare), yang harus tercermin dalam tujuan ( Muladi dan Diah Sulistyani, 2013:33)

Di samping keharusan untuk melakukan harmonisasi terhadap perkembangan hukum yang bersifat universal demi ketertiban hukum antar bangsa di era globalisasi yang bersifat multi dimensional. Tujuan nasional (national goals) merupakan garis kebijakan umum yang menjadi landasan dan sekaligus tujuan pencapaian politik hukum di Indonesia. Tujuan tersebut juga menjadi landasan dan tujuan dari setiap usaha pembaruan hukum, termasuk pembaruan hukum pidana Indonesia.

Sesuai dengan politik hukum pidana maka tujuan pemidanaan harus diarahkan kepada perlindungan masyarakat dari kejahatan serta keseimbangan dan keselarasan hidup dalam masyarakat dengan memperhatikan kepentingankepentingan masyarakat/negara, korban dan pelaku. Dengan demikian, ada dua tujuan yang ingin dicapai oleh hukum pidana dan pidana yaitu pertama "perlindungan masyarakat" dan "kesejahteraan masyarakat". Kedua tujuan tersebut sebagai batu landasan (acornerstone) dari hukum pidana dan pembaruan hukum pidana. Selain itu terdapat pula tujuan ikut serta menciptakan ketertiban dunia sehubungan dengan perkembangan zaman, bahwa kedua istilah ini pun sering dipadatkan dalam satu istilah saja, yaitu "social defence", karena di dalam istilah "perlindungan masyarakat" sudah tercakup juga "kesejahteraan masyarakat" (Arief, 2009: 43).
Sementara itu terkait dengan pembaharuan hukum pidana pasca kemerdekaan, sejatinya sudah dimulai dengan diundangkannya UU No. 1 Tahun 1946 yang diumumkan tanggal 26 Februari 1946 tentang peraturan hukum pidana. Dalam Pasal 5 menegaskan Peraturan hukum pidana, yang seluruhnya atau sebagian sekarang tidak dapat dijalankan, atau bertentangan dengan kedudukan Republik Indonesia sebagai negara merdeka, atau tidak mempunyai arti lagi, harus dianggap seluruh atau sebagian sementara tidak berlaku". Bertitik tolak pada tujuan "perlindungan masyarakat" (social defence), maka tujuan penegakan hukum pidana dapat dibedakan menjadi: (a) perlindungan masyarakat dari perbuatan anti sosial yang merugikan dan membahayakan masyarakat, maka tujuan pemidanaannya adalah mencegah dan menanggulangi kejahatan, (b) perlindungan masyarakat dari sifat berbahayanya seseorang, maka tujuan pemidanaannya adalah memperbaiki pelaku kejahatan atau berusaha mengubah dan mempengaruhi tingkah lakunya agar kembali patuh pada hukum dan menjadi warga masyarakat yang baik dan berguna, (c) perlindungan masyarakat dari penyalahgunaan sanksi atau reaksi dari penegak hukum atau warga masyarakat pada umumnya, maka tujuan pemidanaannya adalah untuk mencegah terjadinya perlakuan atau tindakan sewenangwenang di luar hukum, (d) perlindungan masyarakat dari gangguan keseimbangan atau keselarasan berbagai kepentingan dan nilai akibat dari adanya kejahatan, maka penegakan hukum pidana harus dapat menyelesaikan konflik yang ditimbulkan oleh tindak pidana, dapat memulihkan keseimbangan dan mendatangkan rasa damai dalam masyarakat. Perlindungan masyarakat dalam hal ini mencakup pula secara khusus (Kittichaisaree, 2001: 3).

Perkembangan hukum pidana di luar KUHP tersebut semakin banyak dan ada kecenderungan untuk meninggalkan kaedah atau prinsip-prinsip hukum pidana yang dimuat dalam Ketentuan Umum Hukum Pidana (Buku I KUHP). Kencenderungan ini mengarah pada upaya kriminalisasi norma. Perkembangan pengaturan aspek kriminalisasi baru ini diakibatkan oleh: (a) adanya tuntutan masyarakat terhadap kepentingan hukum baru yang harus dilindungi hukum pidana, (b) kebutuhan bidang hukum lain (hukum perdata dan hukum administrasi/hukum tata usaha negara) yang membutuhkan sanksi hukum pidana untuk 
memperkuat norma-norma dan nilai-nilainya, dan (c) adaptasi terhadap kemerdekaan dan proses demokratisasi.

Harmonisasi terhadap perkembangan internasional dalam bentuk konvensi baik yang sudah atau belum diratifikasi. Sebaliknya ada pula yang berupa dekriminalisasi atau depenalisasi. Undang-undang yang memuat ketentuan hukum pidana baik berupa penghapusan norma hukum pidana, mengubah norma hukum pidana, maupun menambah norma hukum pidana baru dalam KUHP, serta undang-undang yang mengatur norma hukum pidana di luar KUHP baik yang mengatur kaedah hukum yang menyimpang dari aturan umum KUHP maupun yang tidak, dalam perkembangannya dapat dideskripsikan sebagai berikut.

Undang-undang yang memuat ketentuan yang mencabut/ menyatakan tidak berlaku bagi beberapa perumusan delik di dalam KUHP: (1) Undang-Undang Nomor 1 Tahun 1946 tentang Peraturan Hukum Pidana: mencabut/menghapus Pasal 130, Pasal 132, Pasal 133, Pasal 135, Pasal 138, Pasal 139 ayat (1), Pasal 153 bis, Pasal 153 ter, Pasal 161 bis, Pasal 171, dan Pasal 230 KUHP; (2) Undang-Undang Nomor 8 Drt. Tahun 1955 tentang Tindak Pidana Imigrasi: menghapus Pasal 241 sub 1 dan Pasal 527 KUHP; (3) UndangUndang Nomor 20 Tahun 2001 tentang Perubahan Atas Undang-Undang Nomor 31 Tahun 1999 Tentang Pemberantasan Tindak Pidana Korupsi: menyatakan penghapusan Pasal 209, Pasal 210, Pasal 387, Pasal 415, Pasal 416, Pasal 417, Pasal 418, Pasal 419, Pasal 429, Pasal 423, dan Pasal 435 KUHP (yang berkaitan dengan korupsi).

Undang-Undang yang memuat ketentuan yang mengubah perumusan delik/norma hukum pidana dalam KUHP: (1) Undang-Undang Nomor 1 Tahun 1946 tentang Peraturan Hukum Pidana: mengubah beberapa istilah/unsur delik berbahasa Belanda yang ada di dalam KUHP (WvS); (2) Undang-Undang Nomor 1 Tahun 1960 tentang Perubahan Kitab Undang-Undang Hukum Pidana: mengubah ancaman pidana dalam Pasal 188, Pasal 359, Pasal 260 KUHP (delik-delik culpa); (3) Undang-Undang Nomor 16 Prp. Tahun 1960 tentang Beberapa Perubahan dalam Kitab Undang-Undang Hukum Pidana: mengubah katakata "vijf an twintig gulden" menjadi "dua puluh lima rupiah", dalam Pasal 364, Pasal 373, Pasal 379, Pasal 384, dan Pasal 407 ayat (1) KUHP (semuanya kejahatan ringan); (4) Undang-Undang
Nomor 18 Prp. Tahun 1960 tentang Perubahan Jumlah Hukuman Denda dalam Kitab UndangUndang Hukum Pidana dan dalam Ketentuan-Ketentuan Pidana Lainnya yang dikeluarkan sebelum tanggal 17 Agustus 1945: melipatgandakan lima belas kali setiap jumlah ancaman pidana denda dalam KUHP dan dibaca dalam mata uang rupiah; (5) Undang-Undang Nomor 7 Tahun 1974 tentang Penertiban Perjudian: mengubah ancaman pidana untuk delik perjudian dalam Pasal 303 dan Pasal 542 KUHP serta mengubah sebutan Pasal 542 menjadi Pasal 303.

Undang-Undang yang memuat ketentuan yang menambah/memasukkan delik baru ke dalam KUHP, antara lain: (1) Undang-Undang Nomor 8 Tahun 1951 tentang Penangguhan Pemberian Surat Idzin Kepada Dokter dan Dokter Gigi: menambahkan pasal baru yaitu Pasal 512 a (larangan praktek dokter tanpa surat izin); (2) Undang-Undang Nomor 73 Tahun 1958 tentang Menyatakan Berlakunya Undang-Undang No. 1 Tahun 1946 Republik Indonesia Tentang Peraturan Hukum Pidana Untuk Seluruh Wilayah Republik Indonesia dan Mengubah Kitab Undang-Undang Hukum: memasukkan delik "penodaan terhadap bendera kebangsaan" ke dalam Pasal 154 a; (3) Undang-Undang Nomor 1 PNPS Tahun 1965 tentang Pencegahan Penyalahgunaan dan/atau Penodaan Agama: menambahkan/memasukkan delik "penodaam agama" ke dalam Pasal 156a; (4) Undang-Undang Nomor 4 Tahun 1976 tentang Perubahan dan Penambahan Beberapa Pasal dalam Kitab UndangUndang Hukum Pidana Bertalian dengan Perluasan Berlakunya Ketentuan Perundang-undangan Pidana, Kejahatan Penerbangan, dan Kejahatan Terhadap Sarana/ prasarana Penerbangan: menambahkan delik penerbangan dan sarana/ prasarana penerbangan ke dalam Bab XXIX A (Pasal 479a s/d Pasal 479r); (5) Undang-Undang Nomor 27 Tahun 1999 tentang Perubahan Kitab UndangUndang Hukum Pidana yang Berkaitan dengan Kejahatan Terhadap Keamanan Negara: menambah Pasal 107a s/d Pasal 107f (kejahatan terhadap keamanan negara) sebagai konsekuensi dihapuskannya UndangUndang Pemberantasan Kegiatan Subversi (Undang-Undang No.11/PNPS /Tahun 1963).

Undang-Undang yang memuat ketentuan yang membuat perumusan norma hukum pidana sendiri di luar KUHP, yaitu: (1) Undang-Undang 
Nomor 11 Tahun 2008 Tentang Informasi dan Transaksi Elektronik, (2) Undang-Undang Nomor 36 Tahun 1999 Tentang Telekomunikasi, (3) Undang-Undang Nomor 14 Tahun 2001 Tentang Paten.

Berdasarkan pencermatan terhadap perkembangan hukum pidana tersebut, menunjukkan bahwa KUHP atau Wetboek van Strafrecht voor Nederlandsch-Indie (S.1915 No. 732) yang dinyatakan berlaku di Indonesia berdasarkan UU. Nomor 1 Tahun 1946 Jo. UU. Nomor 73 Tahun 1958 baik pada bagian Ketentuan Umum ("general rules"/algemmene deel) yang dimuat dalam Buku I KUHP maupun bagian rumusan Kejahatan (misdrijven) yang dimuat dalam Buku II KUHP, dan rumusan Pelanggaran (overtredingen) yang dimuat dalam Buku III KUHP, tidak lagi dijadikan rujukan utama dalam merumuskan kebijakan legislasi dalam bidang hukum pidana. Dalam konteks inilah seakan-akan terjadi dualisme sistem hukum pidana,yaitu sistem hukum pidana yang dibangun berdasarkan KUHP, dan sistem hukum pidana yang dibangun berdasarkan undang-undang yang tersebar di luar KUHP. Untuk itu perlu ada ikhtiar sesuai kaidah hukum untuk memasukkan nilai-nilai pancasila dalam rancangan undang-undang KUHP yang baru.

Berdasarkan pemaparan di atas, maka perlu dikaji secara lebih mendalam mengenai bagaimana Sejarah Implementasi Nilai Pancasila dalam Hukum Indonesia, dan bagaimana landasan penerapan sistem hukum pidana di Indonesia. Dengan harapan agar mampu memberikan kontribusi pemikiran secara komprehensif mengenai sejarah dan nilai-nilai Pancasila yang sangatlah relevan untuk dimasukkan sebagai ide fundamental dalam sistem hukum di Indonesia. Sekaligus dapat menguraikan implementasi nilainilai Pancasila terutama dalam sistem hukum pidana Indonesia.

\section{SEJARAH DAN IMPLEMENTASI NILAI PANCASILA DALAM PRODUK HUKUM INDONESIA}

Perjalanan sejarah bangsa Indonesia dari kolonial ke kemerdekaan adalah suatu perjalanan paradigmatis. Secara politik berubah dari bangsa pinggiran (periferi) menjadi bangsa yang mengambil alih pusat kekuasaan melalui proklamasi kemerdekaan pada Agustus 1945: dari
Hindia Belanda menjadi Republik Indonesia. Tidak semua bangsa dalam kemerdekaannya ingin membangun suatu kehidupan baru yang didasarkan pada asas-asas baru. Disini peranan Pancasila dan UUD 1945 sangat menentukan terjadinya perubahan yang melompat itu. Pancasila sebagai staatssfundamentalnorm merupakan grand desaign suatu masyarakat dan kehidupan baru di Indonesia. (Raharjo: 1989: 20-21).

Dengan demikian, UUD NRI Tahun 1945 merupakan instrumen yang sangat penting dalam proses membangun masyarakat baru Indonesia dan menjadi modal bagi pembangunan hukum di Indonesia. Oleh karena itu. Ilmu Hukum Indonesia yang bertugas mendeskripsikan dan menjelaskan kehidupan hukum di negeri ini juga tak dapat dipisahkan dari UUD NRI Tahun 1945. Merujuk pada pemikiran tersebut, paradigma yang dapat ditangkap dari UUD NRI Tahun 1945 antara lain: (a) Ketuhanan Yang Maha Esa, (b) Kemanusiaan, (c) Persatuan, (d) Kerakyatan, (e) Keadilan sosial, (f) Kekeluargaan, (g) Harmoni, dan (h) Musyawarah.

Paradigma di atas dapat menuntun dalam bidang penyelenggaraan suatu negara hukum, yakni pembuatan undang-undang, penegakan hukum dan peradilan. Tatanan hukum yang beroperasi dalam suatu masyarakat pada dasarnya merupakan pengejawantahan cita hukum yang dianut dalam masyarakat yang bersangkutan ke dalam berbagai perangkat aturan positif, lembaga hukum dan proses (perilaku birokrsi pemerintahan dan masyarakat) (Sidharta, 1989: 27).

Paham negara hukum yang dianut dalam budaya hukum Indonesia menundukan kepentingan orang perorangan secara seimbang dengan kepentingan umum. Pada arah substansi hukum (legal substance) pidananya, masih dipakainya KUHP (ex. WvS) yang notabene buatan pemerintah kolonial Belanda dan dengan sendirinya berspirit kolonialisme, liberalisme, dan individulisme, hal tersebut jelas bertentangan dengan paham negara kita yang terkandung dalam Pancasila.

Negara Indonesia adalah negara berdasar hukum, penegasan ini secara konstitusional terdapat dalam penjelasan UUD 1945 yang berbunyi: "Negara Indonesia berdasar atas hukum (rechtstaat), tidak berdasar atas kekuasaan belaka (machisstaat)". Disebutkan pula bahwa "Pemerintah Indonesia berdasar atas sistem konstitusi (hukum dasar), tidak bersifat 
absolutisme (kekuasaan yang tidak terbatas). Urgensi penegasan yang dimaksud itu menyebabkan Amandemen ketiga UUD 1945 tahun 2001 ditegaskan kembali dalam pasal 1 ayat (3) yang berbunyi: "Negara Indonesia adalah negara hukum".

Penegasan yuridis-konstitusional sebagaimana tersebut di atas belumlah cukup, akan tetapi harus terimplementasi dalam produk hukum di bawahnya, juga dalam hukum inconcerto di masyarakat. Menurut Frans Magnis-Suseno (1991: 289-301), ada empat syarat atau ciri penting negara hukum yang mempunyai hubungan pertautan atau tali-temali satu sama lain, yaitu: (a) adanya asas legalitas, yang artinya pemerintah bertindak semata-mata atas dasar hukum yang berlaku; (b) adanya kebebasan dan kemandirian kekuasaan kehakiman, terutama dalam fungsinya menegakan hukum dan keadilan; dan (c) adanya jaminan perlindungan terhadap hak asasi manusia.

KUHP yang ada sekarang ini masih identik dengan hukum yang bercitarasa kolonialisme, sehingga seringkali kita temukan penyalahgunaan kekuasaan atau abouse of power, lembaga peradilan yang kurang responsif, putusan-putusan kontroversial baik dalam kasus kecil (seperti: pencurian 3 biji kakao, 2 biji semangka, 4 kg kapas), maraknya kasus mafia hukum/peradilan, penegakan hukum yang belum/kurang optimal termasuk isu tebang pilih, femomena peradilan massa, eigen rechting, maraknya tindak kejahatan dalam masyarakat, dan sebagainya, merupakan bukti bahwa pengejawantahan konsep negara hukum dan nilai-nilai luhur Pancasila dalam praktik kenegaraan dan dalam kehidupan kemasyarakatan belum berjalan sebagaimana yang dicita-citakan.

Pemaknaan KUHP nasional mengalami perkembangan sesuai dengan misi yang dikembangkan: pertama, yang semula sematamata diarahkan kepada misi yang mengandung makna "dekolonisasi" KUHP dalam bentuk "rekodifikasi”. Dalam perjalanan sejarah bangsa, kandungan misi berkembang luas sesuai dengan perkembangan yang ada baik nasional maupun internasional. Kedua, adalah misi "demokratisasi hukum pidana" yang antara lain ditandai dengan masuknya tindak pidana terhadap Hak Asasi Manusia dan dihapusnya tindak pidana penaburan permusuhan atau kebencian (haatzaai-artikelen) yang merupakan tindak pidana formil dan dirumuskan kembali sebagai tindak pidana penghinaan yang merupakan tindak pidana materiil. Misi ketiga adalah misi "konsolidasi hukum pidana" karena sejak kemerdekaan perundang-undangan hukum pidana mengalami pertumbuhan yang pesat baik di dalam maupun di luar KUHP dengan pelbagai kekhasannya, sehingga perlu ditata kembali dalam kerangka Asas-Asas Hukum Pidana yang diatur dalam Buku I KUHP.

Di samping itu penyusunan KUHP baru dilakukan atas dasar misi keempat yaitu misi adaptasi dan harmonisasi terhadap pelbagai perkembangan hukum yang terjadi baik sebagai akibat perkembangan di bidang ilmu pengetahuan hukum pidana maupun perkembangan nilai-nilai, standar serta norma yang diakui oleh bangsabangsa beradab di dunia internasional.

Misi tersebut diletakkan dalam kerangka politik hukum yang tetap memandang perlu penyusunan Hukum Pidana dalam bentuk kodifikasi dan unifikasi yang dimaksudkan untuk menciptakan dan menegakkan konsistensi, keadilan, kebenaran, ketertiban, dan kepastian hukum dengan memperhatikan keseimbangan antara kepentingan nasional, kepentingan masyarakat dan kepentingan individu dalam Negara Republik Indonesia berlandaskan Pancasila dan UUD NRI Tahun 1945.

Menelusuri sejarah hukum pidana di Indonesia, dapat diketahui bahwa KUHP yang berlaku di Indonesia berasal dari Wetboek van Strafrecht voor Nederlandsch-Indie (Staatsblad, 1915:732). Setelah Indonesia merdeka pada tahun 1945, Wetboek van Strafrecht tersebut masih berlaku berdasarkan Pasal II Aturan Peralihan UndangUndang Dasar 1945. Berdasarkan UndangUndang Nomor 1 Tahun 1946 tentang Peraturan Hukum Pidana (Berita Negara Republik Indonesia II Nomor 9), Wetboek van Straftrecht voor Nederlandsch-Indie disebut sebagai KUHP dan dinyatakan berlaku untuk Pulau Jawa dan Madura, sedangkan untuk daerah-daerah lain akan ditetapkan kemudian oleh Presiden. Usaha untuk mewujudkan adanya kesatuan hukum pidana untuk seluruh Indonesia ini, secara de facto belum dapat terwujud karena terdapat daerah-daerah pendudukan Belanda sebagai akibat aksi militer Belanda I dan II di mana untuk daerah-daerah tersebut masih berlaku Wetboek van Strafrecht voor Nederlandsch-Indie (Staatsblad, 1915:732) dengan segala perubahannya. Dengan demikian, dapat dikatakan setelah kemerdekaan tahun 1945 
terdapat dualisme hukum pidana yang berlaku di Indonesia dan keadaan ini berlangsung hingga tahun 1958 dengan diundangkannya UndangUndang Nomor 73 Tahun 1958. Undang-Undang tersebut menentukan bahwa Undang-Undang Nomor 1 Tahun 1946 tentang Peraturan Hukum Pidana dengan semua perubahan dan tambahannya berlaku untuk seluruh Indonesia. Dengan demikian berlakulah hukum pidana materiil yang seragam untuk seluruh Indonesia yang bersumber pada hukum yang berlaku pada tanggal 8 Maret 1942 yaitu "Wetboek van Strafrecht voor Nederlandsch-Indie”, yang untuk selanjutnya disebut Kitab Undang-Undang Hukum Pidana.

Harus diakui bahwa di era Kemerdekaan telah banyak dilakukan usaha untuk menyesuaikan Kitab Undang-Undang Hukum Pidana warisan kolonial dengan kedudukan Republik Indonesia sebagai negara merdeka dan dengan perkembangan kehidupan sosial lainnya, baik nasional maupun internasional. Dalam hal ini di samping pelbagai perubahan yang dilakukan melalui Undang-Undang Nomor 1 Tahun 1946 Jo. Undang-Undang Nomor 73 Tahun 1958, KUHP telah beberapa kali mengalami pembaharuan dan/atau perubahan sebagai berikut: (1) Undang-Undang Nomor 1 Tahun 1960 tentang Perubahan Kitab UndangUndang Hukum Pidana, yang menaikkan ancaman hukuman dalam Pasal-pasal 359, 360 dan 188 KUHP; (2) Undang-Undang Nomor 16 Prp. Tahun 1960 tentang Beberapa Perubahan Dalam Kitab Undang-Undang Hukum Pidana, yang merubah kata-kata "vijf en twintig gulden" dalam Pasalpasal 364, 373, 379, 384 dan 407 ayat (1) Kitab Undang-Undang Hukum Pidana menjadi "duaratus lima puluh rupiah"; (3) Undang-Undang Nomor 18 Prp Tahun 1960 tentang Perubahan Jumlah Hukuman Denda Dalam Kitab Undang-Undang Hukum Pidana dan Dalam Ketentuan Pidana Lainnya Yang Dikeluarkan Sebelum Tanggal 17 Agustus 1945; (4) Undang-Undang Nomor 2 PNPS Tahun 1964 tentang Tata Cara Pelaksanaan Pidana Mati Yang Dijatuhkan Oleh Pengadilan Dilingkungan Peradilan Umum dan Militer; (5) Undang-Undang Nomor 1 PNPS Tahun 1965 tentang Pencegahan Penyalahgunaan/Atau Penodaan Agama, yang antara lain telah menambahkan ke dalam KUHP Pasal 156a ; (6) Undang-Undang Nomor 7 Tahun 1974 tentang Penertiban Perjudian, yang merubah ancaman pidana dalam Pasal-pasal 303 ayat (1), 542 ayat
(1) dan 542 ayat (2) Kitab Undang-Undang Hukum Pidana dan merubah sebutan Pasal 542 menjadi Pasal 303 bis.; (7) Undang-Undang Nomor 4 tahun 1976 tentang Perubahan dan Penambahan Beberapa Pasal Dalam Kitab Undang-Undang Hukum Pidana Bertalian Dengan Perluasan Berlakunya Ketentuan Perundang-Undangan Pidana, Kejahatan Penerbangan, dan Kejahatan Terhadap Sarana/Prasarana Penerbangan.; (8) Undang-Undang Nomor 27 Tahun 1999 tentang Perubahan Kitab Undang-Undang Hukum Pidana Yang Berkaitan Dengan Kejahatan Terhadap Keamanan Negara, khususnya berkaitan dengan kriminalisasi terhadap Penyebaran Ajaran Marxisme dan Leninisme; (9) Undang-Undang Nomor 3 Tahun 1971 yang kemudian digantikan oleh Undang-Undang Nomor 31 Tahun 1999 Jo. Undang-Undang Nomor 20 Tahun 2001, tentang Pemberantasan Tindak Pidana Korupsi, yang pada dasarnya menetapkan beberapa pasal dalam Kitab Undang-Undang Hukum Pidana yang berkaitan dengan Penyuapan dan Tindak Pidana Jabatan menjadi Tindak Pidana Korupsi.

Pembaharuan dan/atau perubahan yang terjadi tersebut pada dasarnya bersifat ad hoc dan bernuansa evolusioner serta tidak dapat memenuhi tuntutan 4 (empat) misi perubahan mendasar yang telah diuraikan di atas (dekolonisasi, demokratisasi, konsolidasi dan harmonisasi), sehingga penyusunan Kitab Undang-Undang Hukum Pidana baru perlu dilakukan dengan tetap memasukkan nilai-nilai Pancasila.

Realitas ini banyak tidak terimplementasikan dalam perumusan hukum, karena bangsa Indonesia banyak lupa akan filosofi bangsa didirikannya negara Indonesia oleh para founding fathers kita. Nilai-nilai luhur yang terkandung dalam dasar negara kita (Pancasila) luntur seiring dengan kemajuan jaman dan teknologi, nilai-nilai yang terkandung di dalamnya seperti ketuhananan, keadilan, kepatutan, keselarasan, persatuan, kemanusiaan dan gotong royong tidak lagi direfleksikan dalam kehidupan berbangsa, bernegara, dan bermasyarakat termasuk juga dalam perumusan produk hukum.

\section{LANDASAN PENERAPAN SISTEM HUKUM PIDANA DI INDONESIA}

Ada sebuah keyakinan dari Bangsa Indonesia yang dinyatakan di dalam Undang-Undang Dasar Negara Republik Indonesia (UUD NRI 
1945) bahwa Indonesia adalah negara kesejahteraan (welfare state). Satu di antaranya tercantum di dalam Pembukaan UUD NRI 1945 yang secara jelas menentukan bahwa salah satu staatsidee Negara Indonesia adalah memajukan kesejahteraan umum (Nugraha: 2004:67). Negara kesejahteraan, menurut Espring-Andersen mengacu pada peran negara yang aktif dalam mengelola dan mengorganisasi perekonomian yang didalamnya mencakup tanggung jawab negara untuk menjamin ketersediaan pelayanan kesejahteraan dasar dalam tingkat tertentu bagi warganya (Tribowo, dkk: 2006: 9). Sejalan dengan pelayanan kesejahteraan dasar tersebut, Ross Cranton, sebagaimana dikutip oleh Safri Nugraha yang menempatkan negara kesejahteraan adalah negara yang menentukan standar minimal kesejahteraan sosial. Di banyak negara, esensi negara kesejahteraan dibebankan pada standar minimal yang dijamin oleh negara, yaitu: penghasilan, pangan, kesehatan, perumahan, dan pendidikan (Nugraha: 2004:45).

Dengan demikian penting kiranya adanya penguatan ideologisasi serta peran negara yang akan berimplikasi pada besarnya peran negara untuk menanam ideology pancasila dalam setiap nafas pembuatan undang-undang. Bahkan Jimly Asshiddiqie menyebutkan bahwa pelembagaan negara kesejahteraan yang demikian ini sebagai intervensionist state (Jimly Asshiddiqie: 2010:2).

Nilai-nilai Pancasila harus menjadi rujukan yang utama dalam perumusan atau pembentukan undang-undang KUHP yang akan dibentuk oleh legislati. Bukan justru karakter dan nilai kolonialisme yang masih melekat dalam KUHP. Setidaknya ada 3 masalah pokok dalam hukum pidana yaitu: (1) tindak pidana, (2) pertanggungjawaban pidana, serta (3) pidana dan pemidanaan, masing-masing merupakan subsistem dan sekaligus pilar-pilar dari keseluruhan bangunan sistem pemidanaan yang harus menginternalisasi nilai-nilai Pancasila. Sebagaimana dimaklumi, aturan pemidanan dalam KUHP (WvS) tidak hanya ditujukan pada orang yang melakukan tindak pidana, tetapi juga terhadap mereka yang melakukan perbuatan dalam bentuk percobaan, pemufakatan jahat, penyertaan, perbarengan (concurus), dan pengulangan (recidive). Hanya saja di dalam KUHP, pemufakatan jahat dan recidive tidak diatur dalam Aturan Umum Buku I, tetapi di dalam Aturan Khusus (Buku II atau Buku III).
Usaha pembaharuan hukum pidana Indonesia yang menginternalisasi nilai-nilai Pancasila harus tetap diarahkan pada tujuan nasional yang ingin dicapai oleh bangsa Indonesia sebagai sebuah negara yang merdeka dan berdaulat. KUHP yang saat ini masih berlaku merupakan produk hukum pemerintah Kolonial Hindia Belanda, yang perlu disesuaikan dengan ideologi bangsa Indonesia yaitu Pancasila.

Alinea keempat Pembukaan UUD NRI Tahun 1945 harus dijadikan tolak ukur untuk pelaksanaan pembaharuan tersebut. Dengan kata lain pembaharuan hukum pidana harus menjadi sarana untuk melindungi segenap bangsa Indonesia dan seluruh tumpah darah Indonesia, memajukan kesejahteraan umum, mencerdaskan kehidupan bangsa, dan ikut melaksanakan ketertiban dunia yang berdasarkan kemerdekaan, perdamaian abadi dan keadilan sosial. Materi hukum pidana nasional harus disesuaikan dengan politik hukum, keadaan, perkembangan kehidupan berbangsa dan bernegara yang bertujuan menghormati dan menjunjung tinggi hak asasi manusia, serta menciptakan keseimbangan berdasarkan nilai Pancasila yaitu landasan moral religius Ketuhanan Yang Maha Esa, kemanusiaan, kebangsaan, kerakyatan, dan keadilan sosial bagi seluruh rakyat Indonesia.

Terkait dengan pembaharuan hukum pidana, paling tidak terdapat dua tujuan yang ingin dicapai oleh hukum pidana yaitu tujuan ke dalam dan tujuan keluar. Tujuan ke dalam, adalah pembaharuan hukum pidana dilakukan sebagai sarana untuk perlindungan masyarakat dan kesejahteraan masyarakat Indonesia. Kedua tujuan tersebut sebagai batu landasan (acornerstone') dari hukum pidana (Arief, ...45) dan pembaruan hukum pidana. Sedangkan tujuan keluar adalah ikut serta menciptakan ketertiban dunia sehubungan dengan perkembangan kejahatan internasional (international crimes) (Kittichaisaree, 2001:3). Perlindungan masyarakat (social defence) dengan penegakan hukum dalam pidana dan pembaharuan pidana yang dilaksanakan dengan tujuan untuk: (1) perlindungan masyarakat dari perbuatan anti sosial yang merugikan dan membahayakan masyarakat, maka tujuan pemidanaan adalah mencegah dan menanggulangi kejahatan, (2) perlindungan masyarakat dari sifat berbahayanya seseorang, maka pidana/ pemidanaan dalam hukum pidana bertujuan memperbaiki pelaku kejahatan atau berusaha 
mengubah dan mempengaruhi tingkah lakunya agar kembali patuh pada hukum dan menjadi warga masyarakat yang baik dan berguna, (3) (3) perlindungan masyarakat dari penyalahgunaan sanksi atau reaksi dari penegak hukum maupun dari warga masyarakat pada umumnya, maka tujuan pidana dirumuskan untuk mencegah terjadinya perlakuan atau tindakan sewenangwenang di luar hukum, (4) perlindungan masyarakat dari gangguan keseimbangan atau keselarasan berbagai kepentingan dan nilai akibat dari adanya kejahatan, maka penegakan hukum pidana harus dapat menyelesaikan konflik yang ditimbulkan oleh tindak pidana, dapat memulihkan keseimbangan dan mendatangkan rasa damai dalam masyarakat.

Perlindungan masyarakat dalam hal ini mencakup pula secara khusus perlindungan korban kejahatan (victim of crime), yang setelah perang dunia kedua mengemuka. Korban dalam hal ini mencakup pula korban "abuse of power", yang harus memperoleh perlindungan berupa "access to justice and fair treatment, restitution, compensation and assistance" (Dijk dan J.M., 1997).

Proklamasi kemerdekaan dan pembentukan Negara Republik Indonesia yang dituangkan ke dalam Undang-Undang Dasar 1945 harus tetap menjadi spirit dalam membawa perubahan besar dalam KUHP yang sebelumnya lebih didominasi oleh dinamakan Hindia-Belanda, termasuk pada penyelenggaraan hukumnya. Implikasinya, secara impisit sudah terjadi perubahan dalam isi cita hukum sebgai "basic guiding principles" dalam penyelenggaraan hukum di Indonesia (Dimyati dan Erwiningsih, 2011).

Secara sosiologis, pembaharuan hukum dilakukan karena adanya kehendak untuk memenuhi kebutuhan hukum masyarakat yang sudah diupayakan sejak 46 tahun yang lalu. Kebutuhan ini didasarkan pada nilai-nilai kebudayaan dari suatu bangsa (latency) yang merdeka dan berdaulat. Terlebih lagi bagi negara yang pernah mengalami masa penjajahan dan saat ini masih mewarisi sistem hukum dari negara yang menjajahnya, baik melalui asas konkordansi, jurisprudensi dan doktrin yang ditanamkan oleh penjajah yang pada perkembangan selanjutnya tidak banyak dipahami oleh generasi baru dari negara tersebut. Pembaharuan hukum bagi negara tersebut mutlak untuk dilakukan sehingga terwujud hukum pidana nasional. Kondisi internal masyarakat Indonesia yang berkembang cepat seiring perkembangan yang terjadi di dunia internasional serta adanya tuntutan akan kepastian hukum dan keadilan yang begitu kuat, menyebabkan beberapa rumusan hukum pidana yang dimuat dalam KUHP tidak lagi dapat dijadikan dasar hukum untuk mengatasi problem kejahatan. Pembaruan hukum pidana yang komprehensif, di dalamnya mengatur keseimbangan antara kepentingan umum dan kepentingan negara dengan kepentingan individu, antara perlindungan terhadap pelaku tindak pidana dan korban tindak pidana, antara unsur perbuatan dan sikap batin, antara kepastian hukum dan keadilan, antara hukum tertulis dan hukum yang hidup dalam masyarakat, antara nilai nasional dan nilai universal, dan antara hak asasi manusia dan kewajiban asasi manusia, menjadi hal yang harus sesegera mungkin diwujudkan. Hal tersebut merupakan keinginan untuk mewujudkan misi dekolinisasi KUHP peninggalan/warisan kolonial, demokratisasi hukum pidana, konsolidasi hukum pidana, dan adaptasi dan harmonisasi terhadap berbagai perkembangan hukum yang terjadi baik sebagai akibat perkembangan di bidang ilmu pengetahuan hukum pidana maupun perkembangan nilai-nilai, standar-standar serta norma yang hidup dan berkembang dalam kehidupan masyarakat hukum Indonesia dan dunia internasional, sekaligus sebagai refleksi kedaulatan nasional yang bertanggungjawab (privilege, control and responsibility).

Landasan Yuridis KUHP yang berlaku di Indonesia saat ini berasal dari Wetboek van Strafrecht voor Nederlandsch-Indie (Stb. 1915: 732). Setelah Indonesia merdeka, keberlakuannya didasarkan Pasal II Aturan Peralihan UndangUndang Dasar 1945. Sampai dengan tahun 1958, masih terjadi dualisme hukum pidana di Indonesia. Baru setelah diundangkannya UndangUndang Nomor 73 Tahun 1958 tentang "Menyatakan Berlakunya Undang-Undang No. 1 Tahun 1946 Republik Indonesia Tentang Peraturan Hukum Pidana Untuk Seluruh Wilayah Republik Indonesia dan Mengubah Kitab Undang-Undang Hukum Pidana", terwujud kesatuan hukum pidana materiil yang seragam untuk seluruh Indonesia yang bersumber pada "Wetboek van Strafrecht voor Nederlandsch-Indie", yang untuk selanjutnya disebut Kitab Undang-Undang Hukum Pidana.

Pada era kemerdekaan telah dilakukan banyak usaha untuk menyesuaikan KUHP warisan kolonial dengan kedaulatan Indonesia dan dengan perkembangan kehidupan sosial lainnya, 
baik nasional maupun internasional. Beberapa pembaharuan dan/atau perubahan yang telah dilakukan terhadap KUHP antara lain dengan: (1) Undang-Undang Nomor 1 Tahun 1960 tentang Perubahan Kitab Undang-Undang Hukum Pidana; (2) Undang-Undang Nomor 16 Prp. Tahun 1960 tentang Beberapa Perubahan Dalam Kitab Undang-Undang Hukum Pidana; (3) UndangUndang Nomor 18 Prp Tahun 1960 tentang Perubahan Jumlah Hukuman Denda Dalam Kitab Undang-Undang Hukum Pidana dan Dalam Ketentuan Pidana Lainnya Yang Dikeluarkan Sebelum Tanggal 17 Agustus 1945; (4) UndangUndang Nomor 2 PNPS Tahun 1964 tentang Tata Cara Pelaksanaan Pidana Mati Yang Dijatuhkan Oleh Pengadilan Dilingkungan Peradilan Umum dan Militer; (5) UndangUndang Nomor 1 PNPS Tahun 1965 tentang Pencegahan Penyalahgunaan/ Atau Penodaan Agama; (6) Undang-Undang Nomor 7179 ICISS, The Responsibility To Protect; (7) Undang-Undang Nomor 1 Tahun 1946 tentang Peraturan Hukum Pidana, Wetboek van Straftrecht voor Nederlandsch-Indie disebut sebagai Kitab Undang-Undang Hukum Pidana Pada Tahun 1974 tentang Penertiban Perjudian; (8) Undang-Undang Nomor 4 tahun 1976 tentang Perubahan dan Penambahan Beberapa Pasal Dalam Kitab Undang-Undang Hukum Pidana Bertalian Dengan Perluasan Berlakunya Ketentuan Perundang-Undangan Pidana, Kejahatan Penerbangan, dan Kejahatan Terhadap Sarana/Prasarana Penerbangan; (9) UndangUndang Nomor 27 Tahun 1999 tentang Perubahan Kitab Undang-Undang Hukum Pidana Yang Berkaitan Dengan Kejahatan Terhadap Keamanan Negara; (10) Undang-Undang Nomor 3 Tahun 1971 yang kemudian digantikan oleh Undang-Undang Nomor 31 Tahun 1999 Jo. Undang-Undang Nomor 20 Tahun 2001, tentang Pemberantasan Tindak Pidana Korupsi.

Apabila dicermati, pembaharuan dan/atau perubahan yang dilakukan masih bersifat sementara (ad hoc) dan bernuansa evolusioner. Oleh karena itu untuk mewujudkan pembaharuan

\section{DAFTAR RUJUKAN}

Arief, Barda Nawawi. 2009. Tujuan dan Pedoman Pemidanaan. Semarang. Badan Penerbit Universitas Diponegoro. dan/atau perubahan yang bersifat mendasar, menyeluruh dan sistemik, perlu disusun KUHP Nasional yang memasukkan nilai-nilai Pancasila yang menggantikan Wetboek van Strafrecht (KUHP) yang merupakan produk hukum pemerintahan zaman kolonial Hindia Belanda.

\section{SIMPULAN}

Sejarah bangsa Indonesia dari kolonial ke kemerdekaan adalah suatu perjalanan paradigmatis. Secara politik berubah dari bangsa pinggiran (periferi) menjadi bangsa yang mengambil alih pusat kekuasaan melalui proklamasi kemerdekaan pada Agustus 1945 dari Hindia Belanda menjadi Republik Indonesia. Hal ini harus berimplikasi pada terinternalisasinya nilainilai Pancasila dalam RUU KUHP. Disini peranan Pancasila sebagai staatssfundamentalnorm dan UUD 1945 sebagai groundnorm sangat menentukan terjadinya perubahan KUHP yang melompat itu.

Selanjunya Keyakinan dari Bangsa Indonesia yang dinyatakan di dalam Undang-Undang Dasar Negara Republik Indonesia (UUD NRI 1945) bahwa Indonesia memiliki nilai-nilai Pancasila harus menjadi rujukan yang utama dalam perumusan KUHP tersebut. Bukan justru karakter dan nilai kolonialisme yang masih melekat dalam KUHP. Setidaknya ada 3 (tiga) masalah pokok dalam hukum pidana yaitu tindak pidana, pertanggungjawaban pidana, serta pidana dan pemidanaan. Selain itu landasan yuridis dan sosiologis dibentuknya KUHP harus terintegrasi dengan Pancasila sebagai landasan Filosofis KUHP Indonesia.

Landasan sosiologis ataupun yuridis dalam pembuatan KUHP di Indonesia harus tetap merujuk kepada nilai-niali Pancasila sebagai satu integrasi dengan landasan filosofis. Hal demikian tentu perlu dilakukan untuk merevitalisasi semangat negara hukum yang diusung the founding fathers demi mewujudkan cita-cita negara Indonesia.
Asshiddiqie, Jimly. 2010. Perkembangan dan Konsolidasi Lembaga Negara Pasca Reformasi. Jakarta:Sinar Grafika. 
Dijk, Jan J.M. Van. 1997. Introducing Victimology, the 9th International Symposium Of The World Society Of Victimology. Amsterdam.

Dimyati, Khudzaifah dan Winahyu Erwiningsih. Orientasi Ilmu Hukum Indonesia. Makalah disajikan dalam seminar nasional kerjasama antara sekertariat MPR dan UMS dengan tema : "Revitalisasi Pancasila Dalam Konteks Kebinekaan Indonesia Saat Ini dan Masa Depan," Surakarta, pada tanggal 19 Mei 2011

Kittichaisaree. 2001. International Criminal Law. U.K. Oxford University Press.

Muladi dan Diah Sulistyani. 2013. Pertanggungjawaban Pidana Korporasi. PT Alumni Bandung.
Nugraha, Safri. 2004. Privatisation of State Enterprises in The 20 ${ }^{\text {th }}$ Century: A Step Forwards or Backwards?, Jakarta: Institute of Law and Economic Studies Faculty of Law University of Indonesia.

Rahardjo, Satjipto. 1980. Hukum dan Masyarakat. Bandung: Angkasa.

Rahardjo, Sajipto. 1989. Paradigma Ilmu Hukum. Bandung:Citra Aditya Bhakti.

Sidharta, B Arief. 1998. Paradigma Ilmu Hukum Indonesia. Bandung; Citra Aditya Bakti.

Suseno, Frans Magnis. 1991. Etika Polotik: Prinsip-Prinsip Moral Dasar Kenegaraan modern. Jakarta: Gramedia. Tribowo, Darmawan dan Sugeng Bahagijo. 2006. Mimpi Negara Kesejahteraan. Jakarta: Pustaka LP3ES Indonesia. 